\title{
COLLECTIVE ENDEAVOURS: FINDING COMMUNITY, LOVE AND HOPE
}

\author{
Margaret S. Malloch
}

\section{Preamble}

A well-rehearsed tale, often shared at mutual aid meetings and featured in an episode of West Wing, tells of a man who is walking down the street when he falls into a hole. The walls are so steep he is unable to get out. A passing doctor who hears his calls for help, writes a prescription, throws it into the hole and moves on. Next, a priest walking past also hears his cries and writes out a prayer, which he also throws into the hole as he continues on his way. Finally, a friend of the man walks past. He recognizes the voice calling for help and jumps into the hole. The man in the hole is aghast: 'Are you stupid?' he cries 'Now we're both down here'. To which his friend replies: 'Yes, but l've been down here before and I know the way out'.

\section{Introduction}

In this paper, we explore the potential for connection and collectivity through the experience of mutual aid as a basis for shared experience and support. Significantly, we then consider the potential this may hold for wider social and political change. Acknowledging the importance of skilled professional support, we challenge the individualising tropes that assume that a combination of professional state 'social' services working with individuals with the 'will' and 'desire' to change, is the most effective way of supporting personal and collective change. Such views, and the promotion of a liberal ideology which they sustain, uphold existing structures of authority, and in doing so, leave the universal effects of power unchallenged.

This paper highlights instead, the limited ability of the state to address or reduce social harm, and indeed, for the state to augment harm through the encroachment of 
its' punitive functions into almost every aspect of life (Wacquant, 2009). The prioritisation of an austerity agenda has resulted in the state's nurturing and caring institutions (welfare, social housing, social work, education) which already exerted a degree of social control (see Piven and Cloward 1971), become increasingly colonised by the state's policing, surveillance and punishing functions (Cooper and Whyte, 2017). This has led to a double regulation of those at the bottom of the social hierarchy and at the margins of the social structure (Wacquant 2009). Social work professionals are often expected to fulfil the role of monitoring and/or managing austerity in a way that prioritises outputs and performance, reinforcing the shift of responsibility for welfare from the state to the individual. In the development of radical social work practice (see for example Ferguson and Woodward 2009, Hill and Laredo, 2019) our analysis is intended to continue ongoing discussion about supporting communities and working with them towards a different state form/transformative system change (see also Weaver and Weaver, 2013 and 2015).

Rather than reform of the state and its institutions, we explore the potential for alternative visions. The examples we provide highlight the significance of independent, autonomous, community based mutual aid groups in which people receive support from other people who have gone through the same, or similar, issues and problems. In order to account for the radical potential of communitybased interventions, we revisit the disruptive and controversial work of Erich Fromm (1900-1980). We draw upon the work of Erich Fromm to make sense of the empirical evidence that we have gathered across several years of research focused on the importance of mutual aid and 'community' as practicei (see De Leon, 1997). We use 
the concept of reciprocal respect and understanding, and a desire to share experiences and solutions, as the core of this mutuality and the basis for a shared sense and experience of community. Undoubtedly ideals and values that feature prominently in aspirational social work practice. This theoretical framework considers the broken social relations that underpin 'addiction' (Alexander, 2008) and other forms of social harm (much of which the state has categorised as 'crime') (Hillyard and Tombs, 2007) as responsive to connection, care and, significantly, collective action. Indeed, this collectivity, we suggest, can provide some degree of antidote to the bureaucratic violence that creates harm through its thoughtless procedures and disengagement from people's lives and experiences.

Mutual aid groups have a long history within the addiction 'recovery' movement, most notably in the form of Alcoholics Anonymous (AA) and the variants of this, which include Narcotics Anonymous (NA) and others. More recently, there has been an emergence of similarly collective-structured groups working as forms of peer support (for example the development of men's groups organised at grass-root level in response to high levels of suicide in local communities). The development of these autonomous, and often networked, groups has relevance for social work in two key ways: first, social workers may be working with individuals who are also engaged in mutual aid groups. Second, it is important to recognise the potential these groups may have for resisting many of the challenges that social work and social workers also face in the current social, political and economic climate. Significantly, these relationships based on mutuality differ from a traditional 'rehabilitative' approach, both in (re)framing issues of 'harm' and the role of professional services. In essence, 
this mutuality seeks to substitute or support the state-sanctioned professional, with those who have been there and who 'know the way out'.

Mutual aid and 'community' as a form of practice draws upon the concept of 'recovery' (for example in relation to mental wellbeing and addiction). In these contexts, experiences of 'recovery' change people - both the individual in recovery and those around them. The recovered individual, energised and supported by the community, is the very factor that re-energises the community in turn through allowing its' members to share their experience with others, and in doing so, helps others move on from difficult circumstances. This mutually reinforcing power constitutes an aspect that is lacking in many, if not most, professionalised forms of intervention; that is the potential to overcome a 'spiritual poverty' (Mclntosh, 2001). Individuals, through engagement with others, are able to find meaning and value that has the potential to overcome the atomism and disconnection inherent for so many in contemporary society.

\section{'Love', 'spiritual emancipation' and the importance of the 'collective'.}

As Fromm (1961) has shown, few areas of knowledge have been more widely misunderstood than the philosophical writings of Karl Marx on the spiritual emancipation of the individual human being through participation in collective action. Fromm illustrates that during the post-war period in both the UK and in the US, a mistaken belief prevailed that Marx's socialism entailed the subordination (or indeed destruction) of the individual in favour of the 'collective' or the 'state'. The opposite of this is true. At the very heart of Marx's project was the spiritual emancipation of the individual human beingii. 
For Marx: "Only in community with others has each individual the means of cultivating his gifts in all directions; only in the community, therefore, is personal freedom possible" (German Ideology, quoted in Selsam and Martel, 1963: 270). Central to this notion of harmony is the concept of community; there is a dialectical relation between the spiritual emancipation of the individual and the creation of community. We therefore consider what this concept might offer for an understanding of personal transformation and potential for collective resistance to the problems of everyday life, which often result in the marginalization and criminalization of those in our most deprived communities. Changes in structures of employment have resulted in significant social insecurity (see Wacquant 2009). Criminalisation and its vindictive application (see Young, 2003) has expanded to address the range of ontological insecurities that have become endemic in contemporary society while substance (mis)use, mental health problems and suicide occur at disturbingly high rates (Samaritans, 2019)iii. As Wacquant (2009) and Young (2003) have argued, social and ontological forms of insecurity have not caused the dissolution of community, they are its consequence.

For Marx, the starting point in the process of 'community' is the full realisation of the individual through liberation from their own alienation, an experience that he attributed to the pressures of economic necessity. Contemporary alienation, manifests in relation to a number of issues including poverty, addiction, mental health problems; the 'taproot' of which McIntosh (2001: 2) refers to as "the great disease of our times - meaninglessness". Likewise, Fromm (1955: 263) notes in a critical analysis of capitalism that people cease to have a 'meaningful life' in their 
required adaptation to a 'sick' society. Those who have "remained a person and not become a thing - cannot help feeling lonely, powerless, isolated in present-day society" (Fromm, 1993: 65). The underpinning economic structure and organization of society was, for Fromm as for Marx, key to all individual experiences.

For Fromm (1957/1975: 15): "The deepest need of man [sic], then, is the need to overcome his separateness, to leave the prison of his aloneness". This separation is evidenced by social circumstances that dislocate people, imposing pressures of individualism, competition and consumerism that result in different forms of 'addiction' as symptomatic of an underlying malaise (Alexander, 2008). The dialectical nature of this process becomes apparent in the observation that individual liberation is only possible through the creation of, and participation in, community. This concept is captured in the need for healing and social justice through rebuilding community and 'spiritual wellbeing' (Mclntosh, 2008; Sawatsky, 2009)iv.

\section{Setting the Scene}

Our evaluations of service provisions and innovative initiatives within criminal justice and other areas of social policy over many years, have shown that meaningful professional interventions have their place. However, they are by no means the only, or indeed always the best, solutions to the myriad of problems that characterize contemporary life. Within the context of bureaucratic structures, statutory responses can often be limited by their attention to the individualization of social, political and economic problems (Crawford, 2015; Crawford and Flint, 2015; Malloch and Mclvor, 2013) focusing on the individual as both the 'problem' to be solved, and the potential 'solution' (through personal attitudinal and/or behavioural change). In contrast, 
however, the power of collective shared experiences can be difficult to access as a basis for 'evidence' of alternatives to professional interventions.

This paper brings together work carried out over an eight-year period from 2011 to 2018. Taking the form of several small and exploratory studies, the aim was to identify and examine the development and operation of support groups and collectives instigated by, and within, local neighbourhoods in Glasgow, Scotland. The different groups covered community-based responses to a variety of social problems and their underlying causes (such as poverty, deprivation, drug and alcohol addiction). The research aimed to consider how 'grass-roots' projects came into existence, how they were sustained and what methods of support they were able to provide for the local people in whose communities they emerged. In particular, responses that addressed material and emotional issues were emphasized alongside how community groups sought to support individuals and to 'transform' their lives through 'community'.

A combination of ethnographic methods (i.e. participant observation) and qualitative data collection (semi-structured interviews) was used across the projects to explore the ways in which collective and mutual aid supported individuals to overcome problems they were experiencing, and in the process, impacted upon their wider community. We draw upon the original findings that emerged from this work and here, explore key theoretical concepts that emerged. This paper draws on the thematic data to emerge from four projects or groups $\vee$ included in the original study. 
Although there were significant differences across the groups and in their central ethos, there were important commonalities. Each group was initiated by a key individual in direct response to their personal experiences and, notably, as a reaction to the circumstances around them; the emergence of a group/project/community developing as local people connected and provided support ${ }^{\mathrm{vi}}$. Importantly, these projects aimed to bring people together around shared concerns in order to address them collectively and collaboratively, in some cases working with statutory services, in others, working with the 'local community' broadly and pragmatically.

All of the groups had started out with no funding or wider support but over time managed to secure this, in some cases quite substantial amounts, at various points in time. However, funding was not consistent often meaning that charitable donations were relied upon or, in the case of one of the groups, contributions from attendees and a local business that allowed use of premises. All groups attempted to resist the co-option of statutory provision in various ways. Autonomy in decision-making, organization and focus was considered important and there was a shared concern that funders could limit this autonomy through their identified priorities. Funding, albeit time-limited and often transitional, had enabled some of the projects to employ workers and access resources; however, each was clearly focused on providing something different from 'professional' servicesvii; participants were referred to variously as 'community members', 'volunteers', and terms like 'client' were rejected. All the groups identified their central aim as helping people relate to the world around them in a way that reintegrated them into a form of 'community'viii. 
The groups (which have been anonymized) were located in areas of Glasgow that had experienced significant economic deprivation and each one had emerged from distinctively different backgrounds: political action and local campaigning; personal experience of drug and alcohol addiction; religious calling; action to address the lack of facilities for young people in a Glasgow housing estate. They operated in different ways (as a community of learning; recovery group organized around sport; a safe space providing daily programmes of activities and companionship; a large community centre offering a range of services organized by and for the local community which included space for various support groups). Stated aims and objectives varied, but all groups had a 'grass-roots' basis and central aim of creating 'community' through their various philosophical contexts which included "reconvening peoplehood", establishing a "recovery community" and "restoring a sense of community"ix.

Access to the groups was obtained through contact with individuals identified as representatives or informal leaders and, after initial meetings to discuss the study, introductions to group participants took place. Once the group had agreed that they were willing to participate in the research, volunteers were invited to take part in semi-structured interviews and/or focus group discussions. Attendance by the researcher/s at events, participation in activities and spending time at each of the projects in informal discussion with participants provided opportunities to observe how the groups functioned. Formal in-depth interviews were conducted with 24 participants (10 women and 14 men) and focus groups took place with participants from three groups (with 6, 11, and 12 participants in each). Interviews were recorded 
and transcribed (where permission was obtained) and detailed field notes were written up .

Qualitative data was coded to identify emergent themes around which the qualitative interview was organised. The dominant issues that arose from this initial grounded 'approach' facilitated a variant of Frame Analysis, applied in order to further refine the codifications and collectively held conventions that were evident across the groups. This formed the material for our final analysis and contributed directly to the

findings that we have presented in this paper. What emerged from the data was a common emphasis on 'community' and a general appreciation of mutual aid and support as underlying principles of group conception and development.

\section{Community in action}

The ethos of the groups expressed specific priorities around which community experiences were organized: the importance of shared experience; a revitalization of meaning in life; and a desire to help others through the transformation of personal experience. Beyond this, a future located utopian 'trace' featured within many of these accounts (Bloch, 1986; Malloch and Munro, 2013), that things could get better, that there was room for hope and that this optimism had potential for resistance and wider social change.

\section{Realizing that you are not alone - others have been there too}

'I met a guy who had been in prison with me who was telling me all about [the group]. He was telling me he was a year sober and all that...I thought he meant he only drank at the weekend. He said 'I don't drink at all, I don't take drugs'. I said, 'how did that work out?' And he was telling us, he was telling us everything. I was intrigued by it ... and I thought that could be my way out of this lifestyle. All I 
was doing was getting drunk, going to jail and it was all part of that vicious circle........] but hearing about it something just twigged in me. 'That's my way out'...(John $\left.{ }^{\mathrm{xi}}\right)$

The importance of feeling welcomed and accepted by a group, people with similar circumstances and experiences to their own, was key for people who had until then, experienced isolation and despair. These circumstances varied: some participants gave examples of addiction, others of bereavement and overwhelming grief, some described having had a 'nervous breakdown' while some participants seemed to have been cast adrift from society. Loneliness and isolation were fundamental problems for participants, but were dissolved, or ameliorated, to varying degrees through connection and in community with others. Association with the group meant that: "'they' becomes 'us' and ' $\mathrm{l}$ ' becomes 'we'" according to one participant, who described the way in which individual connection with others meant no longer feeling alone. This is a fundamental feature of communal recovery such as therapeutic communities and wider 'recovery communities' based on mutual aid (Yates and Malloch, 2010; Roth and Best, 2013). For example, for Anne-Marie (in Yates and Malloch, 2010: 144): "It's the most crucial aspect of 'treatment' - or whatever you want to call it - that you can offer somebody who's shown up saying they want to change their life. To actually give them access to somebody who's been there and done it and will guide them or show them how they did it. And give them hope that they can do it as well. That was the most important thing for me. I had access to people who had done it and knew for themselves what I was going through".

For many of the research participants, experiencing a sense of identification with others, both in terms of their problems and a common solution, was key. Participants 
talked about how important it was to 'be' with others who had experienced similar circumstances and were trying to resolve their difficulties. They could learn from, as well as support each other.

"Being able to be there for each other... everybody has got a phone number, everybody has got a contact number. It's a bond between us all” (Michael).

Many participants, across all the groups, talked about 'bonding' through shared activities. Of significance was the recognition shared by research participants that they needed something more in their lives (recovery, activity, a 'way out') and that they believed they had found this in the company of others with similar experiences:

... I don't know what was in me that day. I just wanted to come in and see what was happening and see if it would help. But see, by the time I came away, I came away feeling that yes, this was going to help (Helen).

Being with others who had overcome similar experiences was important as it 'inspired' those just setting out on their journey:

"The first thing they get is hope that it can be done. Then they start to get inspired by the people around about them. It's as simple as that and it is a community, it's a sober community and it works" (John).

As circumstances began to change for individuals, wider relationships also improved:

"I have kind of bonded better with my family, I have got a better relationship now with my family, my mum and dad...[...]. So it's good to see them, they are kind of...they don't say much but I think they are really proud of me now anyway. I feel a lot better within myself and that's what it's all about..." (Tam) 
Some participants highlighted how important it had been to hear how others, in the same situation they were in, had been able to get out. As time went on, they were then able to share this information with others:

"I am showing you how to get out of it. And that's basically what we are trying to tell them. I went down the exact same road as you" (Michael).

\section{Finding a way to live: (re)awakening the spirit}

Another theme to emerge was the importance of a re-awakening that went beyond the merely physical - the 'spirit', perhaps simply the recognition of a flicker of hope, that started with awareness of shared experience and the suggestion that there was an alternative to the life being lived. The opportunity to reflect on the 'meaning of life' inevitably touches upon ways of living and the spiritual basis of life. This is significantly different to religion, although the two are often confused. For groups such as AA that are based on 12 step programmes, the importance of a 'spiritual experience' is central to recoveryxiii a concept that can take various forms (James 1902[1983]). In mutual aid projects, as exemplified in this research, collective action appeared to offer the individual a sense of experiencing a 'power greater than themselves' (see Bluma, 2018). This was evident in some of the experiences recounted by participants; the meaning of this varied from finding 'religion' within a Christian-based organization to finding a 'higher power' more generally, or to an experience of the "collective" as a source of inspiration and empowerment. Discussing the alienation and automatization of modern society and it's everincreasing 'insanity', Fromm (1955: 352) points out that "In the nineteenth century the problem was that God is dead; in the twentieth century the problem is that man 
[sic] is dead'. For all participants, the group itself provided a space where they felt a 'returning to life'; although represented in different ways, it was reminiscent of a return of their spirit, reminiscent of the will to live (Fromm 1957 and 1993):

"It was a time in my life when I was very ill. l'd had a nervous breakdown; I was at a very low ebb in my life. l'd lost my mum and I never took it very well... [...] I found that [the group] helped me, has helped me in so many ways that doctors couldn't. It gave me a will to live again [...]" (Jenny)

The importance of spirituality is significant for many individuals 'in recovery' who describe having had a 'spiritual experience' which necessitates changes in their lives in order to stay sober (for example Nanoff, 2007). For several of our participants, 'peace of mind' was paramount: "Peace of mind. That's it, that's my long-term goal peace of mind" (Alec). Jack confided: "I think they helped me in a way that no other people could at that time... it was something that I wanted, a bit of contentment, a bit of happiness in my life". The emotional consequences of challenging life events could be addressed in the company of others who were able to provide support. Harry noted:

"I was really an emotional wreck when I first came here and I would say [the group] definitely gave me that grasp over the emotions. Emotions are one of the big things that made me use [drugs]. I had lost my mother at a young age, and my wee brother was murdered, so those things made me drink and [the group] helped me talk about them, it helped me get these things out into the open. And once I started to understand the reasons for using, it was easier for me to try and put them aside and harness that kind of emotion into other stuff'.

The importance of channeling energy and emotions in a positive direction (the art of functioning as a whole person that Fromm refers to as the 'art of being') was picked up by Sarah, who outlined: 
"...we need to become a care orientated society, care for young children, care for the elderly, care for the environment. Those kinds of things need to fill people's lives and give meaning. Spiritual development can be a very important part of that, it might not be legitimatised in the mainstream but ...I would see that as being a crucial area of understanding, to understand that your life perhaps has spiritual meaning. That you might be on a journey, a pilgrimage of life that...is in the course of unfolding. There might be people in places that can help you with that journey".

The relationships which lead to an 'awakening' it would seem, are those in which a degree of mutuality exists (Christie, 1989). However, as Bill noted:

"I am no different from anybody else who has had a spiritual awakening. In the early days I thought I could cure the world and help everybody, and I had to get real through experience, and realise the only people I could help was people who were prepared to help themselves".

\section{Overcoming self-centredness - 'love in action'}

"And anybody new coming in, I would hope for the very first time, would feel the warmth and the affection and the love that people have for one another and for them, as strangers. Because we were there ourselves at one point, that is what teaches you when you want to make people unafraid, so they know it is a good place they are coming into and not a bad place" (Jenny)

For all the groups, there was an understanding that working together and helping one another was a key way to overcome 'self', whether that was simply the alienation experienced as an individual or the limitations of isolation. Different groups saw this in different ways: creating community through 're-rooting notions of identity'; 're-envisioning inclusive forms of community that explore our collective responsibilities, not just our rights'. Acceptance and the warmth experienced within the group was key:

"I think people are drawn to a place that is open, warm and friendly. There is no judgement. You come in and are accepted for who you are. You come into a 
place where people have empathy with you, where they have been through the same thing and feel support. Just a place that is open every day. The drug rehab people - they would only see us for an hour, half an hour a week, that doesn't sustain you. What do you do for the rest of the time?" (Mary)

"You don't get told 'come in here, everything will be all right'. You know they told me when I came in 'this is not going to be easy, it's going to be hard, it's going to be the hardest thing you have ever done in your life you know? And they were right, but it's the most rewarding thing" (Jim)

The dialectical process involved in mutual aid was also evident with a number of participants benefiting from helping others: "It's great to see them getting on and to think you have been a part of it" (Willie). The importance of mutuality, embedded in the process of assistance and support (see also LeBel, 2007 and LeBel et al, 2014) was also reflected in the data in the form of gratitude:

"It's not just clearing your head, you are sitting there talking to somebody and you are worrying about their problems. You are giving them advice, and helping yourself if you know what I mean. You are forgetting your own problems and it puts things into perspective...that's the biggest thing you take from that, gratitude" (Michael)

\section{Resisting the System}

Rather than considering how social problems might be successfully tackled by the state, the problem may need to be entirely recast. We suggest that it is worth exploring how this might be done, not through state-sanctioned professionalized services, but rather through community engagement that involves working closely with people who have been through similar life experiences, and have found their way out. This may also speak to the disillusionment experienced by social work professionals who also often feel alienated from their work and the circumstances that determine their priorities and objectives in the current political and economic 
context (see for example, Yuill, 2018). Collective and compassionate resistance can be considered at both community and professional social work levels, supporting challenges and dissent from the neoliberal state and its' priorities. As Tanner (2019) argues, emotional risks to social workers may not result from the unresolved compassion for those in distress, but instead from the limitations placed upon their desire to act to alleviate that distress.

For both Marx and Fromm, the creation of the 'revolutionary subject' and transformation of society was key. Fromm (1961/2003: 19) quotes Marx: "The coincidence of the changing of circumstances and of human activity or self-changing can only be comprehended and rationally understood as revolutionary practice". When the revolutionary subject and the transformative community align and interact, real potential for change emerges from a sterile, limiting and potentially damaging professionalized service environment. In direct contrast to more professional interventions often focused on the individual, the potential for change through collective endeavor and mutual aid contains within it, the potential for collective resistance. Sivanadan (1990: 39) reminds us of the way in which claims that the 'personal is political' has, in the past, been used to shift attention from the community to the individual, towards a "politics of identity as opposed to a politics of identification". Likewise, Jock Young (1999: 164) notes: "Just as community collapses, identity is invented". However, the collective approach of the groups discussed here, unlike professional individualized intervention, provides a potential to recreate a 'politics of identification', where working with others contains the potential for forms of resistance to the continued undermining of bonds of community in wider society (de-industrialization, poverty, addiction). 
Returning to the work of Erich Fromm, we suggest that the transformational potential arising from communities of mutual support goes beyond 'professionalised' responses to social distress, providing relatedness in the world where the individual can feel 'at home' (Fromm, 1955). Professional responses to symptoms of social distress are prevalent in society today. Limited by their ability to make wider structural changes, professionals within social work, criminal justice, education and other organisations support individuals in a context of increasingly constrained resources. Too frequently, these wider social and economic problems appear to become individualised and re-presented as the result of personal inadequacies which the state is required to manage within pre-determined boundaries.

In this paper, we have drawn attention to concepts that are often overlooked and problematized and to others that are often taken for granted; in essence we seek 'dangerous knowledge' in attempting to 'rescue the imagination' (Young, 2011). This requires an understanding of the deep inequalities of society, the power of the privileged and the system that keeps this in place where "the underlying sanction of punishment usually goes unspoken and thereby renders invisible the violence that keeps justice suppressed" (Mclntosh, 2001: 175).

Drawing on Fromm, our theoretical analysis of the data reveals a perspective from which it is possible to make sense of the interview data in its socially complex and unexpectedly spiritual dimension. As alluded to in the introduction, our participants outlined what was frequently, for them, a transformative journey, both for those seeking support, and those members of the group who, having once been in the same position, were subsequently able to offer support to others. Not only does this 
highlight the truly dialectical process of individual emancipation and the creation of community, it suggests, as does Fromm (1993), that each is interdependent on the other.

The findings section of this paper was structured around our analysis of the process of change and the specific path that this transformative journey took. The first part of the process involved a realisation that the individual was not alone, that others had been in the same situation, and most importantly, that they knew the way out. The second part of the journey involved a 're-awakening', which formed the first steps on a journey of spiritual emancipation. This, the 'misunderstood' core of Marx's entire philosophy (Fromm 1961), reminds us that only in genuine community, is freedom possible. This 're-awakening' takes the form of a journey in what Fromm (1976) would call the transition from 'having' to one of 'being'. The transformation takes place when individuals 'awaken' to the fact that rather than material possessions and the accumulation of externally granted virtues such as esteem, prestige and status, their way out is predicated on what they alone can give each other in their mutuality.

This takes us to the third part of the journey, the transition towards a state of being through love (Fromm, 1976 and 1993). As Fromm (1957) points out, beyond the superficial and narcissistic forms of 'love', it is within community that the various forms of unconditional love can be developed. For Fromm, 'love' is an aspect of the 'productive orientation', "the active and creative relatedness of man to his fellow man, to himself and to nature" (1957:27). It involves caring, responsibility, respect and knowledge of the other person. 
Here we arrive back at the dialectical necessity of individual emancipation through the creation of community. The conduit for this journey from 'having' to 'being' is of course the re-awakening of love. Love for the self and for the other. Thus, for a better society to exist, the revolutionary character, is required (Fromm, 1981 and 1993) who is capable of saying 'no' to [state] power, the non-conformist who can see the world clearly. Returning to our central argument, this process is much more likely when the community of recovery is constituted by people who have 'been there', have found an exit and want to show others the way out.

\section{Openings and escapes}

The often over-looked work of Erich Frommxiii, has here been instrumental in explaining why grass-roots communities can be fundamental to the varied experiences of recovery. Demystifying Marx, Fromm's central message that human flourishing has its roots in the 'spiritual emancipation of the individual' is imperative to understanding the extent to which the building of community is a dialectical process in which both the group and its members benefit.

Through an understanding of this 'community' process, it becomes possible to see the significant limitations for 'state' services run by professionals. Not only do statutory provisions often come to represent forms of governance as mechanisms of social control (Christie, 1981; Cohen, 1985; Garland, 2001), they have also become a technology for the regulation of the poor (Piven and Cloward 1971). Indeed, as Wacquant (2009) argues, when essential support services are taken over by increasingly punitive or regulatory sections of the state, there is a double regulation of those at the margins of the social and economic sphere. As the data in this project 
has shown, mutuality has potential to offer, for some people at least, a way out of this 'authoritarian' trap.

In concluding, we acknowledge the contradictions that have emerged from this study. For the participants, 'real help' comes from those who 'have been through it' and 'know the way out'; perhaps those for whom Christie's (1981/2007) term 'anticlient' may be appropriate (see also his discussion of the Camphill communities, 1989). Yet, as alluded to above, these grass-root groups struggle to compete for both funding and recognition. The other contradiction arises from the fact that solution lies in the transformation from one modality to another, for Fromm that is from 'having' to 'being'. The awakening and emancipation of the individual arises from the realisation that the external world represented by 'having' things, is at the root of their suffering, and that by relinquishing the 'having' mode for the 'being' mode, recovery can be sustained. The obvious irony is that the very notion of professionalism, and the professionalization of services is itself rooted in the 'having' mode since it is driven by 'recognition', 'out-puts', through puts', 'regulatory frameworks', 'financial accountability', 'audits', 'check lists', and an entire range of 'targets' to be met. Herein lies the central issue. The 'real help' that the respondents unanimously favoured is not easily measured.

Mutual aid is based on "a perspective where we no longer see issues such as 'crime', addiction, homelessness or depression as a dysfunction of the individual. Rather they are adaptions of functional individuals to dysfunctional systems operating within wider society. It's not your illness - it is ours" (Macleod, 2017) echoing Fromm (1955 and 1993). Indeed Fromm goes as far as to say (1955: 197): 
"...the very person who is considered healthy in the categories of an alienated world, from the humanistic standpoint appears as the sickest one..." For social work, this presents a space within which to explore working practices and, perhaps transformative journeys away from the limitations of a state-mediated 'official and 'legitimate' discourse, towards a radical alternative in which 'being' is more central, than 'having'. In a consumerist, capitalist society, this means freedom from domination by things and circumstances, ultimately the creation of a new way of being in the world together.

\section{References:}

Alcoholics Anonymous (1939) Alcoholics Anonymous, New York: Dover Publications Alexander, B. (2008) The Globalization of Addiction, Oxford: Oxford University Press.

Anderson, K. and Quinney, R. (2000) (Eds) Erich Fromm and Critical Criminology: Beyond the Punitive Society, Urbana: University of Illinois Press.

Bauman, Z. (2001) Community: Seeking Safety in an Insecure World, Cambridge: Polity.

Bloch, E. (1986) [1938-47] The Principle of Hope Volumes 1-3, Oxford: Basil Blackwell.

Bluma, L. (2018) 'The role of spirituality in alcohol abstinence self-efficacy amongst alcoholics anonymous members', Drugs and Alcohol Today, 18(4): 227-239.

Brent, J. (2009) Searching for Community, Bristol: Policy Press and CYWU.

Bryce, D. with Pia, S. (2005) Alive and Kicking: A Story of Crime, Addiction and Redemption in Glasgow's Gangland, Edinburgh: Mainstream Publishing.

Cheliotis, L. (2010) 'Narcissism, humanism and the revolutionary character in Erich Fromm's work' in L. Cheliotis (Ed) Roots, Rites and Sites of Resistance, Basingstoke: Palgrave Macmillan (p.36-58).

Cheliotis, L. (2011) 'For a Freudo-Marxist Critique of Social Domination', Journal of Classical Sociology, 11(4):438-461. 
Cheliotis, L. (2013) 'Neoliberal capitalism and middle-class punitiveness: Bringing Erich Fromm's 'materialistic psychoanalysis' to penology", Punishment and Society, 15(3): 247-273.

Christie, N. (1981/2007) Limits to Pain, Oregon: Wipf and Stock.

Christie, N. (1989) Beyond Loneliness and Institutions: Communes for Extraordinary People, Norway: Norwegian University Press.

Cohen, S. (1985) Visions of Social Control, Cambridge: Polity Press.

Cooper, V. and Whyte, D. (Eds) (2017) The Violence of Austerity, London: Pluto Press.

Crawford, J. (2015) 'The (Unintended) Consequences of Governance?' Housing, Theory and Society, 32(3): $302-319$.

Crawford, J. and Flint, J (2015) 'Rational fictions and imaginary systems', Politics and Housing, 30(5): 792-807.

De Leon, G. (Ed) (1997) Community as Method, Westport: Praeger Publishers.

Ferguson, I and Woodward, R (2009) Radical Social Work in Practice: Making a Difference. Bristol: Policy Press.

Fromm, E. (1955) The Sane Society, London: Routledge Classics.

Fromm, E. (1961/2013) and Karl Marx, Marx's Concept of Man, London: Bloomsbury.

Fromm, E. (1957/1975) The Art of Loving, London: Unwin Paperbacks.

Fromm, E. (1976) To Have or to Be? New York: Harper and Row.

Fromm, E. (1981) On Disobedience, New York: Harper Collins.

Fromm, E. (1993) The Art of Being, London: Constable.

Garland. D. (2001) The Culture of Control, Oxford: Oxford University Press.

Hill, D. and Laredo, E. (2019) 'First and last and always: streetwork as a methodology for radical community social work practice', Radical and Critical Social Work, 7(1): 25-39.

Hillyard, P. and Tombs, S. (2007) 'From 'crime' to social harm?', Crime, Law and Social Change, 48(9): 11-25.

Holman, B. (1997) FARE Dealing: Neighbourhood involvement in a housing scheme, London: Community Development Foundation Publications. 
Howat, I. and Nicholson, M. (2004) Miracles from Mayhem: The Story of May Nicholson, Ross-shire: Christian Focus Publications.

Howat, I. and Nicholson, M. (2009) More Miracles from Mayhem, Ross-shire: Christian Focus.

James, W. (1983) [1902] Varieties of Religious Experiences, London: Penguin

Kropotkin, P. (1902[2006]) Mutual Aid: A factor in evolution, London: Createspace.

LeBel, T. (2007) 'An Examination of the Impact of Formerly Incarcerated Persons Helping others', Journal of Offender Rehabilitation, 46(1/2): 1-24.

LeBel, T., Richie, M. and Maruna, S. (2014) 'Helping others as a response to reconcile a criminal past', Criminal Justice and Behaviour, 42(1): 108-120.

Lowy, M. (2013) Erich Fromm: From Messianic Utopia to Critical Criminology, Basingstoke: Palgrave Macmillan.

Macleod, G. (2017) 'Galgael 20 years on', Bella Caledonia, 9 August, https://bellacaledonia.org.uk/2017/08/09/galgael-20-years-on/

Malloch, M. (2013) 'The challenge of developing and sustaining a recovery group in Glasgow: Calton Athletic Recovery Group' in J. Roth and D. Best (Ed) Addiction and Recovery in the UK, London: Routledge.

Malloch, M. and Mclvor, G. (2013) (Eds) Women, Punishment and Social Justice, London: Routledge.

Malloch, M. and Munro, W. (2013) Crime, Critique and Utopia: Themes for a Critical Criminology, London: Palgrave.

McIntosh, A. (2001) Soil and Soul, Aurum: London.

McIntosh, A. (2008) Rekindling Community, Devon: Green Books for the Schumacher Society.

Nanoff, P. (2007) Rising from the Dead: Stories of Women's Spiritual Journeys to Sobriety, New York: Haworth Pastoral Press.

Piven, F. and Cloward, R. (1971[1993]) Regulating the Poor: The Functions of Public Welfare, London: Vintage Books.

Roth, J. and Best, D. (2013) Addiction and Recovery in the UK, London: Routledge.

Samaritans (2019) Suicide Statistics Report, Ewell, Surray: Samaritans.

Sawatsky, J. (2009) The Ethic of Traditional Communities and the Spirit of Healing Justice, London: Jessica King Publishers. 
Selsam, H. and Martel, H. (1963) Reader in Marxist Philosophy, New York: International Publishers Co.

Sivanandan, A. (1990) Communities of Resistance, London: Verso.

Tanner, D. (2019) “The Love That Dare Not Speak Its Name': The Role of Compassion in Social Work Practice', British Journal of Social Work, advance article, $1-18$.

Wacquant, L. (2009) Punishing the Poor, Durham NC: Duke University Press.

Weaver, A. and Weaver, B. (2013) 'Autobiography, empirical research and critical theory in desistance', Probation Journal, 60(3): 259-277.

Weaver, B. and Weaver, A. (2015) 'An Unfinished Alternative: Towards a Relational Paradigm' in C. Trotter, G. Mclvor and F. McNeill (eds) Beyond the Risk Paradigm in Criminal Justice, London: Palgrave.

Yates, R. and Malloch, M. (eds) (2010) Tackling Addiction: Pathways to Recovery, London: Jessica Kingsley Publishers

Young, J. (1999) The Exclusive Society, London: Sage Publications.

Young, J. (2003) 'Merton with Energy, Katz with Structure:: The Sociology of Vindictiveness and the Criminology of Transgression', Theoretical Criminology, 7(3): 389-414.

Young, J. (2011) The Criminological Imagination, Cambridge: Polity Press.

Yuill, C. (2018) 'Social workers and alienation: the compassionate self and the disappointed juggler', Critical and Radical Social Work, 6(3): 275-89.

\footnotetext{
'The concept of 'community' is broad (Bauman, 2001), here we use it to refer to a social group who reside in a particular locality.

ii This was true also for Peter Kropotkin, who concludes his book Mutual Aid (1902[2006]: 247) by noting: “And man is appealed to be guided in his acts, not merely by love, which is always personal, or at the best tribal, but by the perception of his oneness with each human being". The concept that we are all One was fundamental to Fromm's concept of love (Fromm, 1957/1975).

iii The suicide rate in Scotland is the highest in the UK - where men aged 35-44 have the highest suicide rate (Samaritans, 2019).

iv Unlike 'professional' or indeed 'academic' discourse, talk of 'meaning' and 'belonging' requires a language that speaks 'a politics of the heart' (McIntosh, 2001).

${ }^{v}$ It is difficult to know what language to use to describe the groups as they defy the more professionalised forms of traditional discourse - they did not describe themselves as 'projects' but variously, 'group' or 'community'.

vi Notable examples of this can be found in Bryce with Pia (2005); Malloch (2013); Howat and Nicholson (2004 and 2009); Holman (1997); McLeod (2017).

vii 'Service to the community' as Brent (2009: 18) illustrates using the work of Raymond Williams can be viewed as a middle class ideal, distinct from the concept of 'solidarity' as 'active mutual responsibility'.
} 
viii Different from professional interventions that have specific tasks to carry out and focus on a formal way of creating 'informal' relationships.

${ }^{i x}$ Thus consideration of referral processes, remit and outputs are of little relevance to their organizational priorites.

Xi Full ethical approval was obtained for the study from the University of Stirling Ethics Committee.

xi Pseudonyms are used throughout the paper.

xii Alcoholics Anonymous claim: "after a while we had to face the fact that we must find a spiritual basis of life or else" (Alcoholics Anonymous, 1939: 44).

xiii For notable exceptions, see Anderson and Quinney (2000); Cheliotis, 2010; 2011; 2013) and Lowy (2013).

This work was supported, in part, by the Carnegie Trust for the Universities of Scotland Award.

The Author declares that there is no conflict of interest.

\section{Acknowledgements}

We would like to thank everyone who participated in this project, sharing their time and experience. Thanks to Dr Joe Crawford, Erasmus Research for his contribution to this article and also to Dr Beth Weaver, University of Strathclyde, for her helpful comments on an earlier version of this manuscript. 